\title{
PREPARATION OF SILVER NANOPARTICLES BY GREEN SYNTHESIS OF VINE SEEDS - ANTIBACTERIAL EFFECT
}

\author{
1,2Branislav RUTTKAY-NEDECKÝ, 1,3,4 Karel SEHNAL, ${ }^{5}$ Dominik BANAS, 1,3Martina STANKOVA, \\ ${ }^{6}$ Marta KEPINSKA, ${ }^{7}$ Duong Ngonc BACH, ${ }^{1}$ Jiri SOCHOR, ${ }^{1}$ Mojmir BARON, ${ }^{8}$ Awais FARID, \\ ${ }^{7}$ Hoai Viet NGUYEN, ${ }^{1,3,4,6}$ René KIZEK \\ ${ }^{1}$ Faculty of Horticulture, Department of Viticulture and Enology, Mendel University in Brno, Lednice, \\ Czech Republic, EU, karelsehnal15@gmail.com, iiri.sochor@mendelu.cz \\ ${ }^{2}$ Department of Molecular Pharmacy, Faculty of Pharmacy, Masaryk University, Brno, Czech Republic, EU, \\ ruttkay-nedeckyb@pharm.muni.cz \\ ${ }^{3}$ Department of Research and Development, ECO-ENVI-NANOLIFE, Prague, Czech Republic, EU \\ ${ }^{4}$ Department of Pharmacology and Toxicology, Faculty of Pharmacy, Masaryk University, Brno, \\ Czech Republic,EU, kizek@sci.muni.cz \\ ${ }^{5}$ Department of Biochemistry, Faculty of Science, Masaryk University, Kamenice, Brno-Bohunice, \\ Czech Republic, EU, dominik.banass@gmail.com \\ ${ }^{6}$ Department of Biomedical and Enviromental Analyses, Faculty of Pharmacy, Wroclaw Medical University, \\ Wroclaw, Poland, EU marta.kepinska@umed.wroc.p I \\ ${ }^{7}$ Research Center for Environmental Monitoring and Modeling, VNU University of Science, Hanoi, Vietnam, \\ nguyenviethoai@hus.edu.vn \\ ${ }^{8}$ Divison of Environment and Sustainability, Hong Kong University of Science and Technology, Kowloon, \\ Hong Kong, awais@ust.hk
}

https://doi.org/10.37904/nanocon.2020.3746

\begin{abstract}
Several silver nanoparticles (AgNPs) with biological effect were prepared by green synthesis. AgNPs were prepared from Vitis vinifera seeds (Merlos variety) used as wine production waste. Green synthesis brings intensive surface modifications of nanoparticles. The seeds were lyophilized and then homogeneously ground. Purified extracts $\left(0.5,2.5,5\right.$ and $10 \mathrm{~g} / 100 \mathrm{~mL}$ water) were added to $\mathrm{AgNO}_{3}$ solution $(1 \mathrm{M})$ in a $1: 1(\mathrm{v} / \mathrm{v})$ ratio and stirred for $24 \mathrm{~h}$. The formed nanoparticles were precipitated with methanol (1:1) $(\mathrm{v} / \mathrm{v})$ and lyophilized. Secondary metabolites were analyzed by various methods. The preparation yield of AgNPs ranged between $3-25 \%$. The total protein values determined by the Lowry method ranged between $1.8-3.6 \mathrm{mg} / \mathrm{mL}$. Antioxidant activity values determined by the CUPRAC method ranged between $76-157 \mu \mathrm{g} / \mathrm{mL}$ GAE. Total phenols values determined by Folin-Ciocalteu ranged between $88-160 \mu \mathrm{g} / \mathrm{mL} \mathrm{GAE}$, by 4-aminoantipyrine method (TAAP) ranged between $728-1,299 \mu \mathrm{g} / \mathrm{mL}$ GAE, by Price Butler method (PBM) ranged between 57 $108 \mu \mathrm{g} / \mathrm{mL}$ GAE. AgNPs prepared from Vitis vinifera seeds (AgNPs-VV) showed also antibacterial activity. Minimal inhibition concentration (MIC) of AgNPs-VV in S.aureus was $31 \mu \mathrm{g} / \mathrm{mL}$ and MIC in E. coli was 55 $\mu \mathrm{g} / \mathrm{mL}$.
\end{abstract}

Keywords: Green synthesis, phenolic compounds, analytical methods, antibacterial effects; traditional medicine, ethnobotany

\section{INTRODUCTION}

Chemotherapeutics based on natural sources are very intensively searched and studied [1,2]. Secondary plant metabolites involve a number of groups of substances [3]. At the beginning of the $21^{\text {st }}$ century there is still a 
major concern of infections arising from improper use of antibiotics, disinfectants in hospitals and still not wellunderstood mechanisms [4]. Preventing these infections is not easy [4]. According to statistics, more people die from bacterial infections than from injuries and cancer $[5,6]$. The observed rapid rise in bacterial resistance requires the search for new strategies [6]. One of the possible solutions seems to be the use of nanotechnologies [7]. Some types of nanoparticles, including silver nanoparticles (AgNPs), show antimicrobial, antiviral and antifungal effects [8]. In addition, green synthesis of AgNPs uses enzymes and plant extracts [8]. It has lower costs, is environmentally friendly and does not require the use of high pressure and temperature [8]. In addition, important groups are represented by phenolic structures, which have antitumor, antiviral and antibacterial properties [9]. Stilbenes are very important in this area [10]. Stilbenes are part of foods and beverages such as blueberries, peanuts, grapes and red wine [11]. Vine is one of the most important sources of phenolic compounds (including stilbenes). These phenols are present in the skins and seeds [12] and they are shown in Figure 1. Resveratrol is the most studied stilbene, which has positive health effects [10]. The wine industry produces a number of wastes (wood, cane, and root) in the production of wine. Modification of the nanoparticle surface with these secondary metabolites can bring a number of completely new properties that can be used in biological applications [13].<smiles>CC(C)(C)OC(=O)O</smiles>
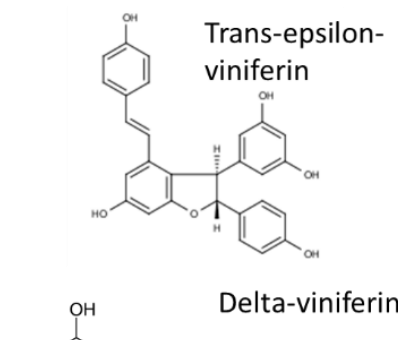

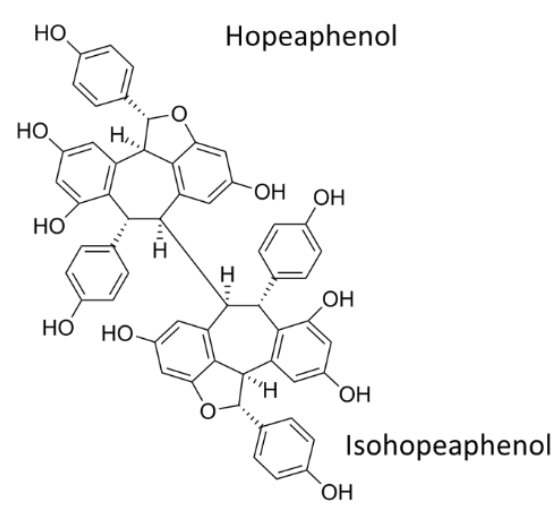<smiles>O=C1c2c(O)cc(O)cc2OC(c2cc(O)c(O)c(O)c2)C1O</smiles><smiles>OC1=CC(/C=C/c2ccc3c(c2)C(c2ccc(O)cc2)C(c2ccc(O)cc2)O3)=CCC1</smiles>

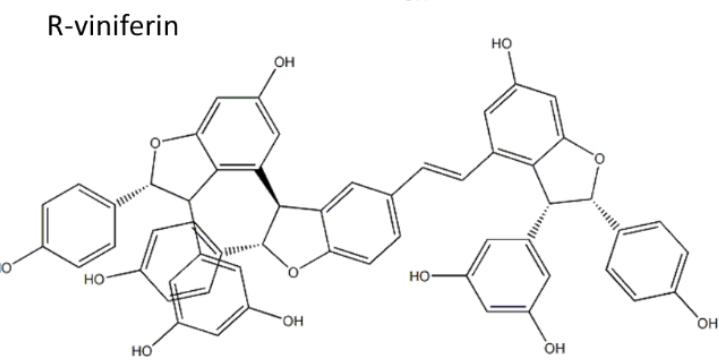

Figure 1 Oligostilbens are a major component of stilbenes extracted from these wastes. An important group of stilbenes in wine are: resveratrol, ampelopsin A, trans-epsilon-viniferin, delta-viniferin, hopeaphenol, isohopeaphenol, and $r$-viniferin $[14,15]$.

The aim of this work was to design new types of AgNPs from the waste product of Vitis vinifera seeds and to test their antibacterial activity.

\section{MATERIAL AND METHODS}

AgNPs from Vitis vinifera AgNPs-VV. Short description of nanoparticle preparation: Immediately after collection, the plants were washed in distilled water and divided into smaller parts. Seeds of grape Merlot (Lednice, Czechia) were obtained during processing of the grapes into wine. The seeds were washed and lyophilized ( $48 \mathrm{~h},-80^{\circ} \mathrm{C}, 1 \mathrm{mbar}$ ), then homogenized by grinding, using a laboratory grinder (Retsch, GM 200, 
Germany) ( $3 \mathrm{~min}, 10,000 \mathrm{rpm})$. The material thus prepared was used to prepare the plant extract. Plant extracts were prepared from various amounts of plant material $(0.5 ; 2.5 ; 5.0 ; 10.0 \mathrm{~g} / 100 \mathrm{~mL}$ ultrapure water). The extracts were stirred at $25^{\circ} \mathrm{C}$, on a magnetic stirrer $(600 \mathrm{rpm}, 60 \mathrm{~min})$. They were then centrifuged (20 min, $14,000 \mathrm{~g}$ ). Each plant extract was filtered and allowed to cool to room temperature. After filtration, the plant extracts were mixed with $0.1 \mathrm{M} \mathrm{AgNO}_{3}$ in a $1: 1(\mathrm{v} / \mathrm{v}$ ) ratio and allowed to stir with a magnetic stirrer (IKA RH basic, Malaysia) at room temperature $\left(23^{\circ} \mathrm{C}\right)$ for 18 hours. The purified nanoparticles were centrifuged $(14,000 \mathrm{~g}, 30 \mathrm{~min})$ and the pellet was lyophilized $\left(24 \mathrm{~h},-77^{\circ} \mathrm{C}, 0.6 \mathrm{mbar}\right)$. The yield of the reaction was determined.

Photometric characterization of the extract. VIS absorption spectra were measured in the $400-750 \mathrm{~nm}$ range. During the formation of nanoparticles, the colour of the resulting solution gradually changed (increasing the absorbance in the area of $450 \mathrm{~nm}$ due to the formation of nanoparticles). (Biochemical analysis of AgNPs surface was performed on BS-300 automatic analyzer (Mindray, China). DPPH (2,2-diphenyl-1-picrylhydrazyl), ABTS (2,2'-azino-bis(3-ethylbenzothiazoline-6-sulfonic acid) and FRAP (ferric reducing ability of plasma) methods were used for sample analysis $[16,17]$. The extracts were characterized by spectrophotometric methods for the content of phenolic substances (Folin Ciocalteau, 4-aminoantipyrine method - TAAP, Price Butler method - PMB) and proteins (Lowry method, pyrogallol red).

Antibacterial activity of AgNPs-VV. Escherichia coli a Staphylococcus aureus were obtained from the Collection of Microorganisms of Masaryk University Brno (cultivation of stock culture LB medium, $37^{\circ} \mathrm{C}, 24 \mathrm{~h}$ ). Infinite F50 (Tecan, Switzerland) was used for measurements. The antibacterial activity of the AgNPs-VV prepared by green synthesis was determined by the microdilution method, with some modifications. Different volumes of the stock solution AgNPs-VV and broth media were added to 96-well microtiter plates to obtain tested concentrations with a final volume of $250 \mu \mathrm{L}$. Then a 1-10 $\mu \mathrm{L}$ of the microbial inoculums were inoculated in microtiter plate wells to obtain a final concentration of $10^{4} \mathrm{cells} / \mathrm{mL}$. The plates were incubated for $24 \mathrm{~h}$ at $30{ }^{\circ} \mathrm{C}$ and after incubation, viable cell numbers were enumerated, and the $\mathrm{CFU} / \mathrm{mL}$ were determined. The growth curves were determined for $24 \mathrm{~h}$ at $30{ }^{\circ} \mathrm{C}$ in a sterile microtiter plate $(0.3 \mathrm{ml}$, shaking $5 \mathrm{~s}, 150 \mathrm{rpm})$. Measurements were performed on an Infinite 50 (Tecan, Switzerland) at $620 \mathrm{~nm}$. Absorbances were recorded every $15 \mathrm{~min}$.

Mathematical and statistical analysis. Experimental work was performed in at least three independent experiments. Each sample in the experiments was analysed at least five times. The obtained data presented in this paper are the average values. No experimental points were excluded from the proposed experimental study. All the obtained data were stored in the Qinslab database. If possible, data were processed and evaluated mathematically and statistically in the Qinslab database. The results were expressed as mean \pm standard deviation (SD). Positive and negative controls were included in all assays. Probit analysis used to determine the minimum inhibitory concentration (MIC).

\section{RESULTS AND DISUSSION:}

\subsection{Preparation of new AgNPs-VV from Vitis vinifera seed (Merlos variety)}

In our previous experimental work, approaches for the synthesis and characterization of AgNPs were optimized [18]. The effect of obtaining dry and dispersed nanoparticles on the time of sonication was studied in detail on AgNPs prepared with extracts of tea, wormwood and sage (the effect was studied as an increase in the A450 absorbance signal). Elevated temperature drying $\left(60^{\circ} \mathrm{C}, 24 \mathrm{~h}\right)$ and lyophilization $\left(-80^{\circ} \mathrm{C}, 0.1 \mathrm{mbar}, 48 \mathrm{~h}\right)$ were used to dry the nanoparticles. After the drying process, the nanoparticles were prepared at a concentration of $10 \mathrm{mg} / \mathrm{mL}$. They were then dispersed in a conventional ultrasonic bath (4 W for a maximum of 300 minutes). For AgNPs prepared using extracts of Vietnamese tea, wormwood, sage after drying and dispersion, the absorbance ranged $0.1-1.4 ; 0.05-1.0 ; 0.05-0.6\left(y=-0.0934+0.0124 x+0.00001 x^{2}, R^{2}=0.988 ; y=-\right.$ $\left.0.0114+0.0030 x, R^{2}=0.976 ; y=0.0143+0.0009 x+0,00001 x^{2}, R^{2}=0,953\right)$, respectively and after 
lyophilization, the absorbance ranged $0.6-1.60 ; 0.1-1.2 ; 0.2-1.0\left(y=0.4600+0.0077 x+0.00001 x^{2}, R^{2}=\right.$ $\left.0.991 ; y=0.1683+0.0032 x, R^{2}=0.976 ; y=0.1475+0.0058 x+0.00001 x^{2}, R^{2}=0.993\right)$, respectively. The results clearly showed that the lyophilization process improves the dispersibility of the nanoparticles and the process further depends on the type of extract used. We applied these conditions for the preparation of new AgNPs-VV. Extracted from lyophilized seeds in amounts $(0.5 ; 2.5 ; 5.0 ; 10.0 \mathrm{~g} / 100 \mathrm{~mL})$ were prepared. The prepared extracts were characterized by visual coloration. The yield increased (from 3 to $25 \%$ ) linearly depending on the amount used $(y=2.339 x+1.771, r=0.999)$. According to the optimized procedure, AgNPsVV were prepared, in which we focused on the introduction of new methods for the evaluation of flavonoids present in grapevine seeds.

\subsection{Automated analysis of phenolic compounds in V. vinifera extracts}

New methods have been introduced for the characterization of plant extracts and silver nanoparticles in terms of quantification of phenolic substances, proteins, antioxidant activity and flavonones. CUPRAC method, which is based on the principle of reduction of $\mathrm{Cu}^{2+}$-neocuproine complex to $\mathrm{Cu}^{+}$-neocuproine due to antioxidants present in the sample (Figure 2). The measurement of the resulting complex was at $450 \mathrm{~nm}$. In addition, it was possible to fully automate the method. As a control for the stability of the method, a control chart was created for the gallic acid concentration of $25 \mu \mathrm{g} / \mathrm{mL}$ and $12.5 \mu \mathrm{g} / \mathrm{mL}$, where the average value of the control chart for 7 days ( $58804 \pm 1964 \mathrm{mAU}$ and $34461 \pm 2360 \mathrm{mAU})$.
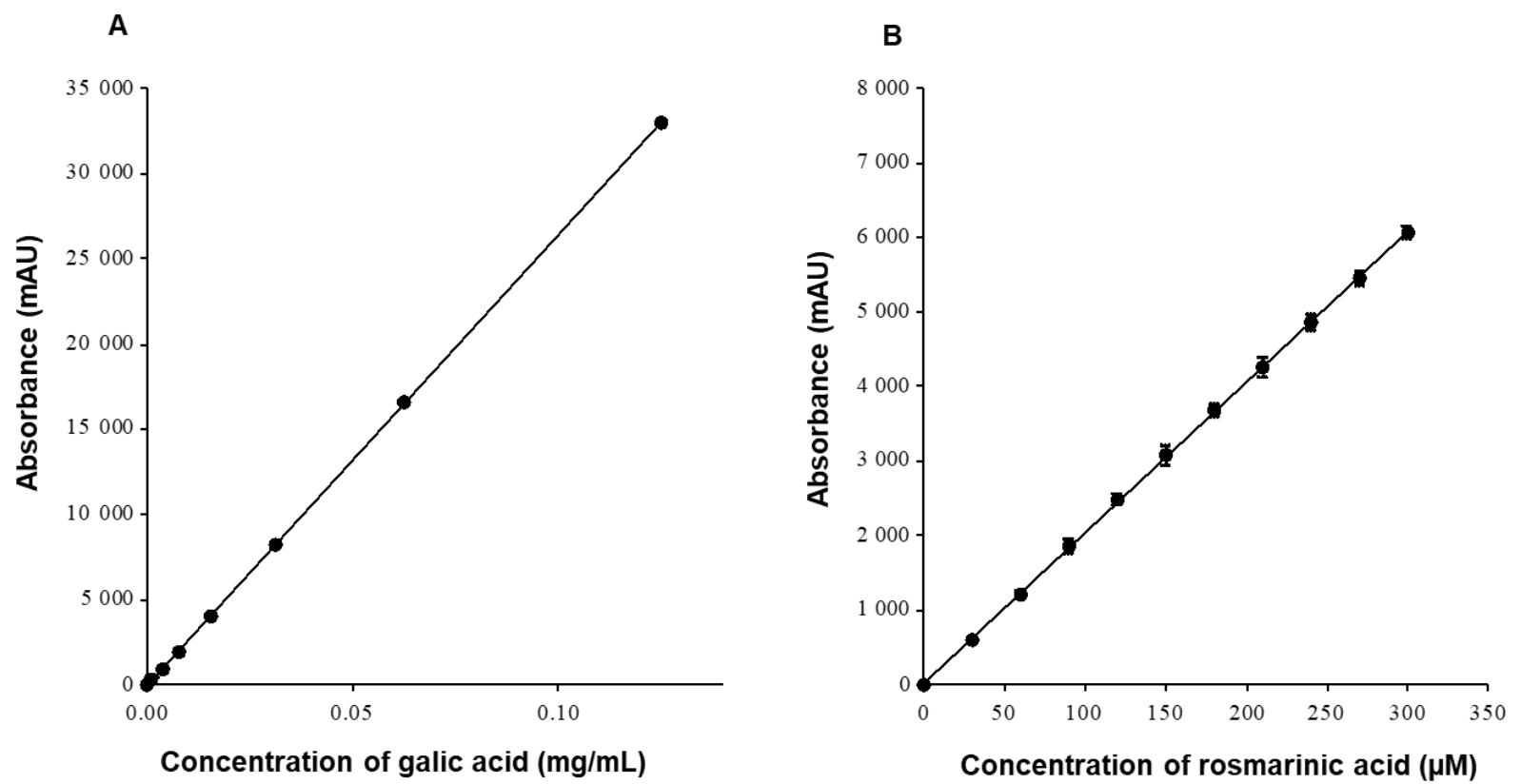

Figure 2 Evaluation of antioxidant activity using the CUPRAC method. The activity is expressed as the equivalent of gallic acid (A). Typical dependence of absorbance on rosmarinic acid concentration (B).

The FLAVANONES method, which is based on the reaction of flavanones of plant extracts with 2,4-DNPH and after subsequent alkalization, results in a quantitative black-blue coloration of the solution. The measurement of the resulting complex was at $505 \mathrm{~nm}$ and the method could be fully automated. As a control for the stability of the method, a control chart was created for the concentration of hesperetin $6 \mu \mathrm{g} / \mathrm{mL}$, where the average value of the control chart for 7 days (4012 $\pm 323 \mathrm{mAU}$ ). The Price Butler method (PBM), which is based on the reaction of a mixture of ferric chloride and potassium ferrocyanide with phenolic substances in a slightly acidic medium. The measurement of the color complex was at $740 \mathrm{~nm}$ and the method could be fully automated. As a control for the stability of the method, a control diagram for the concentration of gallic acid $13 \mu \mathrm{g} / \mathrm{mL}$ was created, where the average value of the control diagram for 7 days (58068 $\pm 3573 \mathrm{mAU})$. TAAP method, which 
is based on the reaction of a mixture of potassium ferricyanide and 4-aminoantipyrine in an alkaline medium. The measurement of the resulting complex was at $450 \mathrm{~nm}$ and the method could be fully automated. As a control for the stability of the method, a control diagram for the gallic acid concentration of $53 \mu \mathrm{g} / \mathrm{mL}$ was created, where the average value of the control diagram for 7 days (3947 $\pm 368 \mathrm{mAU})$. The methods used showed very good reproducibility and stability during the analysis of the obtained samples. Individual analyzes were performed in the used plant extracts. We found that the content of total phenols determined by the FolinCiocalteu method ranged from 0.2 to $1.4 \mathrm{mg} / \mathrm{mL}$ GAE, by TAAP method ranged between $0.1-1.2 \mathrm{mg} / \mathrm{mL}$ GAE, by Price Butler method (PMB) ranged between $0.1-0.8 \mathrm{mg} / \mathrm{mL}$ GAE. We paid special attention to the analysis of flavanones. Their content ranged from 0.07 to $0.47 \mathrm{mg} / \mathrm{mL}$ hesperetin, 0.06 to $1.17 \mathrm{mg} / \mathrm{mL}$ silimarin and by CUPRAC method from 0.13 to $0.95 \mathrm{mg} / \mathrm{mL}$ GAE. The amount of total protein ranged from 1 to $6 \mathrm{mg} / \mathrm{mL}$ of extract. Analyzes were also performed in AgNPs-VV. Total phenols values determined by Folin-Ciocalteu ranged between $88-160 \mu \mathrm{g} / \mathrm{mL}$ GAE, by TAAP method ranged between $728-1,299 \mu \mathrm{g} / \mathrm{mL}$ GAE, by PBM method ranged between $57-108 \mu \mathrm{g} / \mathrm{mL}$ GAE. The total protein values determined by the Lowry method ranged between $1.8-3.6 \mathrm{mg} / \mathrm{mL}$.

\subsection{AgNPs-VV antibacterial activity}

Developing bactericidal surfaces using simple chemical methods can be a very promising way to many applications. Antibacterial activity was determined on model organisms ( $S$. aureus, E. coli). Growth curves were measured for individual bacterial strains (24 h). We found that AgNPs-VV showed $35-50 \%$ inhibitory activity of the control (S.aureus or E.coli without AgNPs-VV). AgNPs-VV showed higher antibacterial activity against $S$. aureus and lower antibacterial activity against $E$. coli. Based on the calculation of the $\mathrm{IC}_{50}$, the MIC of AgNPs-VV in S. aureus was determined to be $31 \mu \mathrm{g} / \mathrm{mL}$ and MIC of AgNPs-VV in E.coli was $55 \mu \mathrm{g} / \mathrm{mL}$.

\section{CONCLUSION}

There is still very little information on the behavior of nanoparticles in the environment. In addition to chemical synthesis, green synthesis is an alternative that can improve the degradability of nanoparticles from the environment. AgNPs-VV were prepared from several extracts from $V$. vinifera seeds. Total phenols were determined by different methods in both seed extracts and AgNPs-VV. It was shown, that AgNPs-VV contained phenols and had antioxidant activity. AgNPs-VV also showed antibacterial activity against both $S$.aureus and E.coli. Our results show that the application of green chemistry processes improves the synthesis of AgNPs and probably improves their potential use in biological applications.

\section{ACKNOWLEDGEMENTS}

\section{The work was carried out with the support of the H2020 CA COST Action CA18, NAKI_ID1902015 and Liga proti Rakovině Praha.}

\section{REFERENCES}

[1] LI, F. S., WENG, J. K. Demystifying traditional herbal medicine with modern approaches. Nature Plants. 2017, vol. 3, no. 8, p. 7.

[2] TEIXIDOR-TONEU, I., JORDAN, F. M., HAWKINS, J. A. Comparative phylogenetic methods and the cultural evolution of medicinal plant use. Nature Plants. 2018, vol. 4, no. 10, pp. 754-761.

[3] CHONG, J. L., POUTARAUD, A., HUGUENEY, P. Metabolism and roles of stilbenes in plants. Plant Science. 2009, vol. 177, no. 3, pp. 143-155.

[4] LIBERTUCCI, J., YOUNG, V. B. The role of the microbiota in infectious diseases. Nature Microbiology. 2019, vol. 4, no. 1, pp. 35-45. 
[5] DABBAGH, A., LAWS, R. L., STEULET, C., DUMOLARD, L., MULDERS, M. N., KRETSINGER, K., ALEXANDER, J. P., ROTA, P. A., GOODSON, J. L. Progress Toward Regional Measles Elimination - Worldwide, 2000-2017. Mmwr-Morbidity and Mortality Weekly Report. 2018, vol. 67, no. 47, pp. 1323-1329.

[6] LI, M., DU, X., VILLARUZ, A. E., DIEP, B. A., WANG, D. C., SONG, Y., TIAN, Y. R., HU, J. H., YU, F. Y., LU, Y., OTTO, M. MRSA epidemic linked to a quickly spreading colonization and virulence determinant. Nature Medicine. 2012, vol. 18, no. 5, pp. 816-U217.

[7] MURA, S., NICOLAS, J., COUVREUR, P. Stimuli-responsive nanocarriers for drug delivery. Nature Materials. 2013, vol. 12, no. 11, pp. 991-1003.

[8] KUMAR, A., VEMULA, P. K., AJAYAN, P. M., JOHN, G. Silver-nanoparticle-embedded antimicrobial paints based on vegetable oil. Nature Materials. 2008, vol. 7, no. 3, pp. 236-241.

[9] MATTIO, L. M., CATINELLA, G., DALLAVALLE, S., PINTO, A. Stilbenoids: A Natural Arsenal against Bacterial Pathogens. Antibiotics-Basel. 2020, vol. 9, no. 6, pp. 40.

[10] AJA, I., RUIZ-LARREA, M. B., COURTOIS, A., KRISA, S., RICHARD, T., RUIZ-SANZ, J.-I. Screening of Natural Stilbene Oligomers from Vitis vinifera for Anticancer Activity on Human Hepatocellular Carcinoma Cells. Antioxidants. 2020, vol. 9, no. 6, p. 469.

[11] SNOPEK, L., MLCEK, J., SOCHOROVA, L., BARON, M., HLAVACOVA, I., JURIKOVA, T., KIZEK, R., SEDLACKOVA, E., SOCHOR, J. Contribution of Red Wine Consumption to Human Health Protection. Molecules. 2018, vol. 23, no. 7, p. 16.

[12] GOUFO, P., SINGH, R. K., CORTEZ, I. A Reference List of Phenolic Compounds (Including Stilbenes) in Grapevine (Vitis vinifera L.) Roots, Woods, Canes, Stems, and Leaves. Antioxidants. 2020, vol. 9, no. 5, p. 33.

[13] HOSNEDLOVA, B., SOCHOR, J., BARON, M., BJORKLUND, G., KIZEK, R. Application of nanotechnology based-biosensors in analysis of wine compounds and control of wine quality and safety: A critical review. Critical Reviews in Food Science and Nutrition. 2020, vol. 60, no. 19, pp. 3271-3289.

[14] TAKAYA, Y., YAN, K.-X., TERASHIMA, K., HE, Y.-H., NIWA, M. Biogenetic reactions on stilbenetetramers from Vitaceaeous plants. Tetrahedron. 2002, vol. 58, no. 45, pp. 9265-9271.

[15] ZACHOVÁ, Z., TŘíSKA, J., VRCHOTOVÁ, N., BALÍK, J., SAJFRTOVÁ, M., SOVOVÁ, H. Combining highpressure methods for extraction of stilbenes from grape cane. The Journal of Supercritical Fluids. 2018, vol. 142, pp. 38-44.

[16] OU, B. X., HUANG, D. J., HAMPSCH-WOODILL, M., FLANAGAN, J. A., DEEMER, E. K. Analysis of antioxidant activities of common vegetables employing oxygen radical absorbance capacity (ORAC) and ferric reducing antioxidant power (FRAP) assays: A comparative study. Journal of Agricultural and Food Chemistry. 2002, vol. 50, no. 11 , pp. 3122-3128.

[17] RE, R., PEllegrini, N., PROTEGgente, A., PANNALA, A., YANG, M., RICE-EVANS, C. Antioxidant activity applying an improved ABTS radical cation decolorization assay. Free Radical Biology and Medicine. 1999, vol. 26, no. 9-10, pp. 1231-1237.

[18] SEHNAL, K., LY, P. T., UHLIROVA, D., DUNG, M. L., STANKOVA, M., XUAN, T. T., VSETICKOVA, M., ANH, N. N., HOSNEDLOVA, B., KEPNSKA, M., RUTTKY-NEDECKY, B., BACH, D. N., MILNEROWICZ, H., PRAKASH, T., HUNG, N. T., NGUYEN, H. V., KIZEK, R. Green synthesis of silver nanoparticles using plants originating in tropical areas of vietnam for biological applications. In: 11th International Conference on Nanomaterials Research \& Application - NANOCON 2019. Brno: Tanger, 2019, pp. 463-468. 